\title{
ANALISIS HUKUM ISLAM TERHADAP PRAKTIK ABORSI BAGI KEHAMILAN TIDAK DIHARAPAKAN (KTD) AKIBAT PERKOSAAN MENURUT UNDANG-UNDANG NOMOR 36 TAHUN 2009 TENTANG KESEHATAN
}

\author{
Titik Triwulan Tutik ${ }^{1}$
}

\begin{abstract}
Abstrak
Abortion practice could be noted as hidden phenomenon by its enigmatic and more over is layered by the actor, community also government. Obstruction itself is under bearing of legal system, social norms, culture, religion those living in the people lifes. Under her research the author sets up reconfimation that both Islamic Law and Health Law have same dogma that abortion practice is criminal conduct. But under specific circumstance abortion possibly will be achieved. That might is ought to refers to medical ethic as if then in pratice should not worse impact to the woman whom raped. Under Islamic Law preference is also ought to refers to stipulated syar'i.
\end{abstract}

Kata kunci: hukum islam, praktik aborsi, kehamilan, perkosaan, undangundang kesehatan

\section{Pendahuluan}

Dampak kasus Kehamilan Tidak Dikehendaki (KTD) khususnya korban perkosaan, pada dasarnya membawa akibat buruk - selain korban mengalami trauma yang panjang bahkan seumur hidup, dia tidak dapat melanjutkan pendidikan, tidak dapat bersosialisasi dengan lingkungannya. Begitu juga jika anaknya lahir, masyarakat tidak siap menerima kehadirannya bahkan mendapat stigma sebagai anak haram yang tidak boleh bergaul dengan anak-anak lain di lingkungannya serta menerima perlakuan negatif lainnya. Sementara jika digugurkan (aborsi), selain tidak ada tempat pelayanan yang aman dan secara hukum dianggap sebagai tindakan kriminal, pelanggaran norma agama, susila dan sosial.

${ }^{1}$ Penulis adalah Dosen Fakultas Syari'ah IAIN Sunan Ampel Surabaya. Alamat korespondensi: Fakultas Syari'ah IAIN Sunan Ampel Surabaya, Jl. Jend. A. Yani No. 117 Surabaya. 
Kasus Kehamilan Tidak Dikehendaki (KTD) yang berakhir dengan aborsi tidak aman, hanyalah salah satu kasus yang terjadi di Indonesia. Pusat Penelitian Kesehatan Universitas Indonesia menemukan, pertahun rata-rata terjadi sekitar 2 juta kasus aborsi tidak aman. ${ }^{2}$ Sementara WHO memperkirakan $10-50 \%$ dari kasus aborsi tidak aman berakhir dengan kematian ibu. ${ }^{3}$ Angka aborsi tak aman (unsafe abortion) memang tergolong tinggi, diperkirakan setiap tahun di dunia terjadi sekitar 20 juta aborsi tak aman, 26\% dari jumlah tersebut tergolong legal dan lebih 70.000 aborsi tak aman di negara berkembang berakhir dengan kematian ibu. ${ }^{4}$

Muhajir Darwin dari Pusat Penelitian Kependudukan UGM dalam Round Table Discussion, tentang Aborsi, Usia Kawin dan Pengaruhnya terhadap Fertilisasi yang diadakan BKKBN, mengatakan:

...ketika hukum tidak memberi tempat bagi pelayanan aborsi yang aman, maka para perempuan yang mengalami kehamilan tanpa dikehendaki terpaksa per ke bidan'atau dukun aborsi yang tak kompten. Akibatnya, kompliaksi kesehatan atau bahkan kematian mengancamnya.

Selanjutnya menurut Muhajir Darwin, bahwa angka kematian maternal di Indoonesia adalah tertinggi di Asia yaitu sekitar 11\% di antaranya karena pertolongan aborsi yang tidak aman. ${ }^{6}$

${ }^{2}$ Budi Utomo, dkk. Angka Aborsi dan Aspek Psiko-sosial di Indonesia: Studi di 10 kota Besardan 6 kabupaten (Jakarta: Pusat Penelitian Kesehatan Universitas Indonesia, 2002), hal. 7

3 WHO dalam Gulardi Wignyosastro. Masalah Kesehatan Perempuan Akibat Reproduksi. Makalah Seminar Penguatan Hak Reproduksi Perempuan, diselenggarakan PP Fatayat NU, pada 1 September 2001.

${ }^{4}$ The Alan Guttmacher Institute (AGI), "Sharing Responsibility: Women, Society and Abortion Worldwide", New York: AGI, p. 35, dalam Martha S. Ismail. Promosi Kesehatan Reproduksi: Pencegahan Kehamilan yang Tidak Diinginkan/Kehamilan yang Tidak Direncanakan.

${ }^{5} 2$ Juta Perempuan Per Tahun Lakukan Aborsi, Harian Terbit Jum'at 23 Mei 2003, hal. 8 kolom $1-5$

${ }^{6}$ Data tahun 1995 menunjukkan dari 600.000 perempuan meninggal karena kehamilan dan persalinan. Dari angka itu 66.000 perempuan meninggal karena aborsi. Sementara Zarfel Tafal dari FKM UI dan aktif di PKBI mencatat dari pengalaman praktiknya di sebuah klinik di Jakarta ada kecenderungan permintaan aborsi semakin meningkat. Tahun 1999 sekitar 100.000 perempuan, namun tahun 2000-an sudah menjadi 200.000-an lebih di 8 klinik. Ibid. 
Aborsi pada dasarnya adalah fenomena yang hidup dalam masyarakat Indonesia. Aborsi dapat dikatakan sebagai fenomena "terselubung" karena praktik aborsi sering tidak tampil ke permukaan, bahkan cenderung ditutupi oleh pelaku utaupun masyarakat, bahkan negara. Ketertutupan ini antara lain dipengaruhi oleh hukum formal dan nilai-nilai sosial, budaya, agama yang hidup dalam masyarakat serta politik.

Secara hukum, aborsi diatur dalam Kitab Undang-Undang Hukum Pidana Pasal 283, 299, 346, 348, 349, 535 dan Kitab Undang-Undang Hukum Perdata Pasal 2 dan 1363. Pada intinya pasal-pasal tersebut menyatakan bahwa tuntutan dikenakan bagi orang-orang yang melakukan aborsi ataupun orang-orang yang membantu melakukan baik secara langsung maupun tidak langsung.?

Pada intinya hukum formal yang mengatur masalah aborsi menyatakan bahwa pemerintah Indonesia menolak aborsi. Pengecualian diberikan jika ada indikasi medis sebagaimana tercantum dalam Undang-Undang Kesehatan Nomor 23. Tahun 1992 Pasal 15 dan Pasal 80. Selain itu, masalah aborsi juga terkait dengan Sumpah Dokter Indonesia yang antara lain menyatakan bahwa dokter akan menghormati setiap kehidupan. ${ }^{8}$

Keberadaan praktik aborsi kembali mendapat perhatian dengan disyahkannya Undang-Undang Nomor 36 Tahun 2009 Tentang Kesehatan. Meski demikian UU ini menimbulkan kontroversi diberbagai lapisan masyarakat karena adanya pasal-pasal yang mengatur mengenai aborsi dalam praktek medis mengandung berbagai reaksi. Pasal 75 dan 76 UndangUndang Nomor 36 Tahun 2009, kembali menegaskan bahwa pada dasarnya UU melarang adanya praktik aborsi (Pasal 75 ayat 1). Meski demikian larangan tersebut dikecualikan apabila ada:

a. indikasi kedaruratan, medis yang dideteksi sejak usia dini kehamilan, baik yang mengancam nyawa ibu dan/atau janin, yang menderita penyakit genetik berat dan/atau cacat bawaan, maupun yang tidak dapat diperbaiki sehingga menyulitkan bayi tersebut hidup di luar kandungan; atau

b. kehamilan akibat perkosaan yang dapat menyebabkan trauma psikologis bagi korban perkosaan (Pasal 75 ayat 2).

Terlepas dari hukum formal yang mengatur, aborsi merupakan fenomena yang terkait erat dengan nilai-nilai sosial budaya agama yang

${ }^{7}$ Dewi dalam Indraswati, "Fenomena Kawin Muda dan Aborsi: Gambaran Kasus", dalam Hasyim, S. "Menakar 'Harga' Perempuan", (Jakarta: Mizan, 1999), hal. 132

${ }^{8}$ Ibid. 
hidup dalam masyarakat. Dalam konteks Indonesia aborsi lebih condong sebagai $a i b$ sosial daripada manifestasi kehendak bebas tiap individu. Aborsi merupakan masalah yang sarat dengan nilai-nilai sosial, budaya, agama, dan politik. Aturan normatif legal formal menolak aborsi meski masih ada ruang untuk hal-hal khusus. Aturan normatif sosial-hudaya-agama yang "informal" pada umumnya juga menolak aborsi, meski terdapat variasi dan kelonggaran di sana-sini.

Persoalan aborsi penting untuk dibahas karena fenomena ini berkaitan erat dengan persoalan kesehatan reproduksi perempuan. Untuk kasus Indonesia, seperti diketahui, salah satu penyebab tingginya angka kematian ibu (MMR) adalah karena praktek aborsi terutama bagi ibu pada usia belia sebagai akibat salah pergaulan ataupun belum siap memiliki anak, selain persoalan pelayanan kesehatan yang tidak memadai dan faktor struktural lain yang lebih luas. Selain keterkaitan dengan nilai-nilai sosial, politik, budaya, dan agama, secara lebih spesifik fenomena aborsi tersebut terkait erat dengan isu gender.

Kasus Kehamilan Tidak Dikehendaki (KTD) yang berakhir dengan aborsi, selain tidak ada tempat pelayanan yang aman dan secara hukum dianggap sebagai tindakan kriminal, pandangan agama (fikih) yang berkembang di masyarakat pun cendérung tunggal yaitu melarang aborsi. Padahal dalam hal tersebut, pemikiran fikih yang berkembang di masa kejayaan para imam madzhab tempo dulu cukup beragam dan dapat memberikan solusi secara syar'iy.

II. Praktik Aborsi Bagi Kehamilan Tidak Diharapakan (KTD) Akibat Perkosaan Menurut Undang-Undang Nomor 36 Tahun 2009 Tentang Kesehatan

\section{Aborsi Kehamilan Tidak Diharapakan (KTD) Akibat Perkosaan Menurut Kesehatan Reproduksi}

Secara medis, aborsi adalah berakhirnya atau gugurnya kehamilan sebelum kandungan mencapai usia 20 minggu atau berat bayi kurang dari $500 \mathrm{~g}$, yaitu sebelum janin dapat hidup di luar kandungan secara mandiri. Angka kejadian aborsi meningkat dengan bertambahnya usia dan terdapatnya riwayat aborsi sebelumnya. Proses abortus dapat berlangsung secara:

1. Spontan/alamiah (terjadi secara alami, tanpa tindakan apapun);

2. Buatan/sengaja (aborsi yang dilakukan secara sengaja); 
3. Terapeutik/medis (aborsi yang dilakukan atas indikasi medik karena terdapatnya suatu permasalahan atau komplikasi).

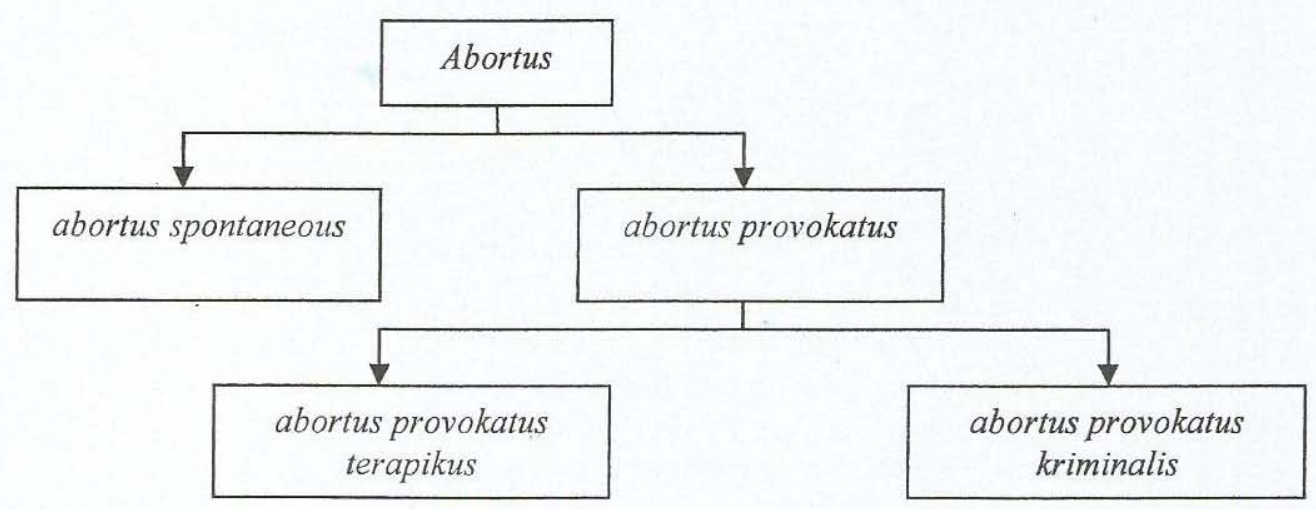

Gambar. 1 Kategorisasi Abortus

Frekuensi terjadinya aborsi di Indonesia sangat sulit dihitung secara akurat karena banyaknya kasus aborsi buatan/sengaja yang tidak dilaporkan. Berdasarkan perkiraan dari BKBN, ada sekitar 2 juta kasus aborsi yang terjadi setiap tahunnya. Pada penelitian di Amerika Serikat terdapat 1,2 - 1,6 juta aborsi yang disengaja dalam 10 tahun terakhir dan merupakan pilihan wanita Amerika untuk kehamilan yang tidak diinginkan. Secara keseluruhan, di seluruh dunia, aborsi adalah penyebab kematian yang paling utama dibandingkan kanker maupun penyakit jantung.

Tindakan aborsi mengandung risiko yang cukup tinggi, apabila dilakukan tidak sesuai standar profesi medis. Berikut ini berbagai cara melakukan aborsi yang sering dilakukan:

(1) Manipulasi fisik, yaitu dengan cara melakukan pijatan pada rahim agar janin terlepas dari rahim. Biasanya akan terasa sakit sekali karena pijatan yang dilakukan dipaksakan dan berbahaya bagi oragan dalam tubuh;

(2) Menggunakan berbagai ramuan dengan tujuan panas pada rahim. Ramuan tersebut seperti nanas muda yang dicampur dengan merica atau obat-obatan keras lainnya;

(3) Menggunakan alat bantu tradisional yang tidak steril yang dapat mengakibatkan infeksi. Tindakan ini juga membahayakan organ dalam tubuh. ${ }^{9}$ 


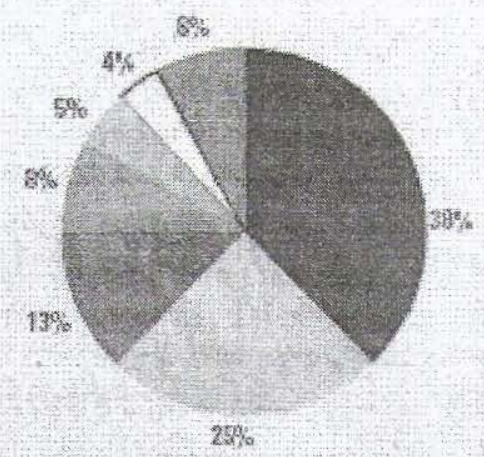

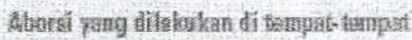
pala

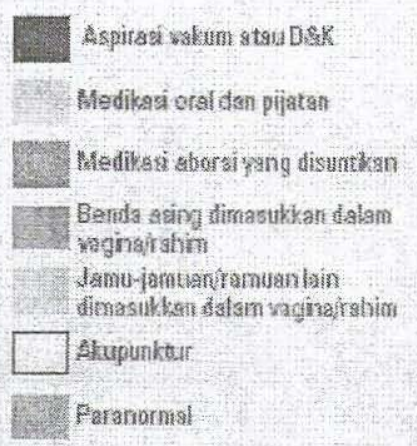

Gbr. 2 Beberapa metode aborsi (Sbr.: Utomo, B., 2000)

Adapun alasan mereka melakukan tindakan aborsi tanpa rekomendasi medis adalah:

(1) Ingin terus melanjutkan sekolah atau kuliah. Perlu dipikirkan oleh pihak sekolah bagaimana supaya tetap dipertahankan sekolah meski sedang hamil kalau terlanjur;

(2) Belum siap menghadapi orang tua atau memalukan orang tua dan keluarga. Hal ini juga perlu legawa orang tua karena psikologis anak sangat besar;

(3) Malu pada lingkungan sosial dan sekitarnya;

(4) Belum siap baik mental maupun ekonomi untuk menikah dan mempunyai anak;

(5) Adanya aturan dari kantor bahwa tidak boleh hamil atau menikah sebelum waktu tertentu karena terikat kontrak; dan

(6) Tidak senang pasangannya karena korban perkosaan. ${ }^{10}$

Aborsi yang dilakukan secara sembarangan sangat membahayakan kesehatan dan keselamatan ibu hamil bahkan sampai berakibat pada kematian. Perdarahan yang terus menerus serta infeksi yang terjadi setelah tindakan aborsi merupakan sebab utama kematian wanita yang melakukan aborsi. Selain itu aborsi berdampak pada kondisi psikologis dan mental seseorang dengan adanya perasaan bersalah yang menghantui mereka. Perasaan berdosa dan ketakutan merupakan tanda gangguan psikologis. 
Beberapa akibat yang dapat timbul akibat perbuatan aborsi, yaitu:

(1) Pendarahan sampai menimbulkan shock dan gangguan neurologis/syaraf di kemudian hari, akibat lanjut perdarahan adalah kematian;

(2) Infeksi alat reproduksi yang dilakukan secara tidak steril. Akibat dari tindakan ini adalah kemungkinan remaja mengalami kemandulan di kemudian hari setelah menikah;

(3) Risiko terjadinya ruptur uterus (robek rahim) besar dan penipisan dinding rahim akibat kuretasi. Akibatnya dapat juga kemandulan karena rahim yang robek harus diangkat seluruhnya;

(4) Terjadinya fistula genital traumatis, yaitu timbulnya suatu saluran yang secara normal tidak ada yaitu saluran antara genital dan saluran kencing atau saluran pencernaan. ${ }^{11}$

Resiko komplikasi atau kematian setelah aborsi legal sangat kecil dibandingkan dengan aborsi ilegal yang dilakukan oleh tenaga yang tak terlatih. Beberapa penyebab utama resiko tersebut antara lain: Pertama, sepsis yang disebabkan oleh aborsi yang tidak lengkap, sebagain atau seluruh produk pembuahan masih tertahan dalam rahim. Jika infeksi ini tidak segera ditangani akan terjadi infeksi yang menyeluruh sehingga menimbulkan aborsi septik, yang merupakan komplikasi aborsi ilegal yang fatal. Kedua, perdarahan. Hal ini sebebakan oleh aborsi yang tidak lengkap, atau cedera organ panggul atau usus. Ketiga, efek samping jangka panjang berupa sumbatan atau kerusakan permanen ti tuba fallopi (saluran telur) yang menyebabkan kemandulan. ${ }^{12}$

${ }^{11}$ Ibid.

${ }^{12}$ Erica Royston dan Sue Arnstrong (Eds), "Preventing Maternal Deaths", Terj. RF Maulany, "Pencegahan Kematian Ibu Hamil", (Jakarta: Binaputra Aksara, 2004), hal. 122123. 


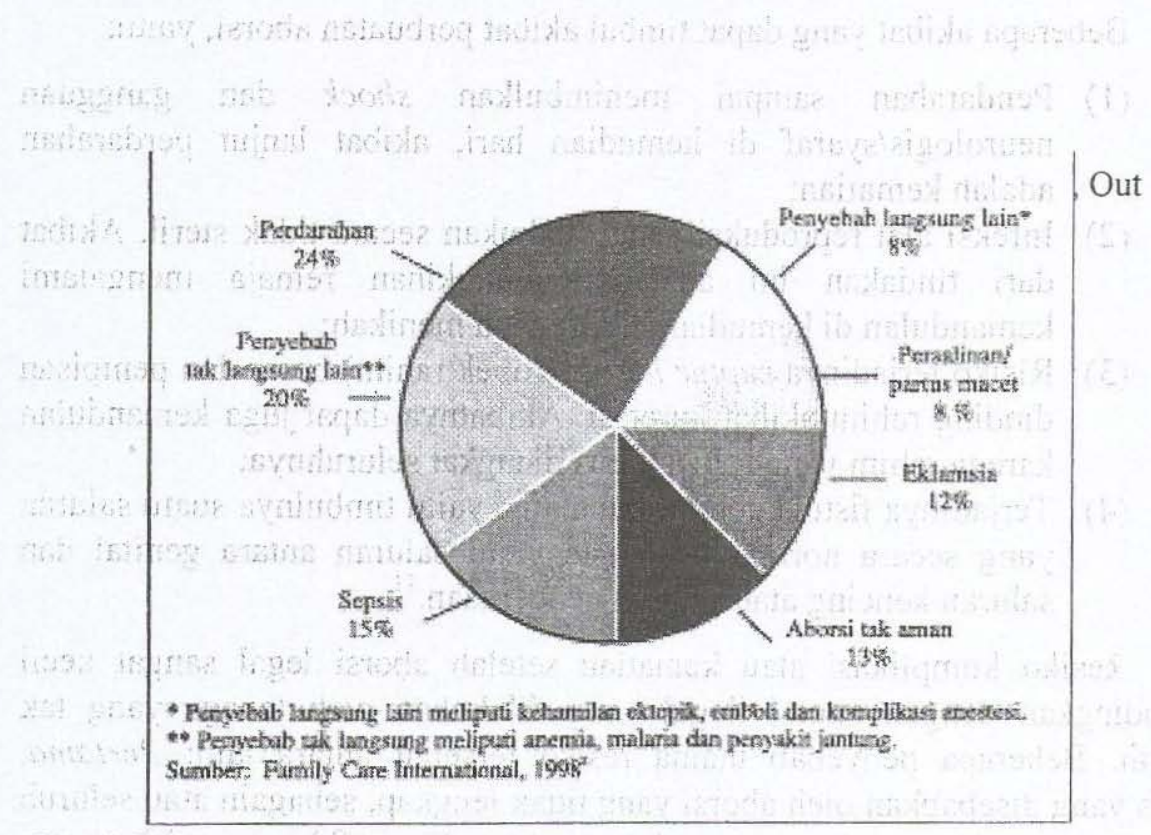

\section{Praktik Aborsi Kehamilan Tidak Diharapakan (KTD) Akibat Perkosaan Menurut Undang-Undang Nomor 36 Tahun 2009 Tentang Kesehatan}

Ketentuan tentang hukum aborsi di dalam hukum pidana positif Indonesia diatur di dalam KUHP (Lex Generalis) dan Undang-Undang Kesehatan (Lex Spesialis). Menurut Supriyadi, ${ }^{13}$ KUHP tidak membolehkan aborsi dengan alasan apa pun juga dan oleh siapapun juga. $^{14}$ Ketentuan ini sejalan dengan diundangkannya di zaman pemerintahan Hindia Belanda sampai dengan sekarang ini tidak pernah berubah., dan ketentuan ini berlaku umum bagi siapa pun yang melakukan, bahkan bagi dokter yang melakukan dikenakan pemberatan pidana. Namun berdasarkan UUK, apabila terdapat indikasi medis dalam keadaan darurat dan untuk menyelamatkan jiwa

${ }^{13}$ Supriyadi, 2001, Politik Hukum Kesehatan terhadap Pengguguran Kandungan, Makalah disampaikan dalam Diskusi Ilmiah, Aborsi Dari kajian Ilmu Politik Hukum, (Hukum Kesehatan dan Hukum Pidana), Yogyakarta: Bagian Hukum Pidana, FH-UAJY, tanggal 2 Juli 2002, hal. 12

${ }^{14}$ Lihat Kitab Undang-Undang Hukum Pidana Pasal 283, 299, 346, 348, 349, 535 dan Kitab Undang-Undang Hukum Perdata Pasal 2 dan 1363. 
ibu, maka tenaga kesehatan tertentu yang mempunyai kewenangan bertindak, dapat melakukan aborsi. ${ }^{15}$ Berdasarkan ketentuan UUK, meskipun bahasa yang digunakan untuk aborsi adalah samar-samar, secara umum hukum tersebut mengijinkan aborsi bila perempuan yang akan melakukan aborsi mempunyai surat dokter yang mengatakan, bahwa kehamilannya membahayakan kehidupannya, surat dari suami atau anggota keluarga yang mengijinkan pengguguran kandungan, test laboratorium yang menyatakan perempuan tersebut positif dan pernyataan yang menjamin, bahwa setelah melakukan aborsi perempuan tersebut akan menggunakan kontrasepsi. ${ }^{16}$

Walaupun secara jelas dan tegas aborsi dilarang oleh undangundang, dalam realita kehidupan sehari-hari, hal tersebut banyak sekali terjadi atau dilakukan karena berbagai alasan sebagaimana dikemukakan oleh Ekotama, dkk. ${ }^{17}$ dan Tafal, dkk. ${ }^{18}$ Bahkan Dewi ${ }^{19}$ mengatakan, bahwa jumlah aborsi di dalam kehidupan masyarakat cenderung meningkat karena berbagai faktor sehingga dia menyimpulkan bahwa motivasi perempuan melakukan aborsi berkaitan erat dengan akseptor KB dan kehamilan di luar nikah.

Berbeda dengan pendapat di atas, menurut Indraswari, kasus aborsi tidak menunjukkan karakteristik khusus terutama bila dilihat dari segi pendidikan dan status pernikahan. Ada kecenderungan, aborsi adalah suatu fenomena yang menimpa masyarakat lintas strata sosial ekonomi, pendidikan, budaya, dan agama. ${ }^{20}$

Selanjutnya Indraswati mengatakan: Kesehatan.

${ }^{15}$ Lihat Pasal 15 dan Pasal 80 Undang-Undang Nomor 23 tahun 1992 tentang

${ }^{16}$ Guttmacer Institute, Aborsi di Indonesia, Seri 2008, No. 2, hal. 1.

17 Ekotama, dkk., "Abortus Provocatus Bagi Korban Perkosaan: Perspektif Viktimologi, Kriminologi dan Hukum Pidana", (Yogyakarta: Universitas Atmajaya, 2001), hal. 26 hal. 34 .

${ }^{18}$ Tafal, dkk., eds., "Keguguran", (Jakarta: ITF Netherlands, IPPF, dan PKBI, 1999),

${ }^{19}$ Dewi, "Aborsi: Pro dan Kontra di Kalangan Petugas Kesehatan", (Yogyakarta: Pusat Penelitian Kependudukan UGM dan Ford Foundation, 1997), hal. 40.

${ }^{20}$ Indraswati, "Fenomena Kawin Muda dan Aborsi: Gambaran Kasus", dalam Hasyim, S., "Menakar 'Harga' Perempuan", (Jakarta: Mizan, 1999), hal. 150. 
... terdapat kecenderungan peningkatan praktik aborsi yang dilakukan oleh pelajar SMP dan SMA, alumnus SMA (pekerja), dan mahasiswa. Hal ini sejalan dengan perubahan pola interaksi dan pola gaya hidup yang melanda kalangan remaja dan dewasa muda. ${ }^{21}$

Apa yang dikemukan tersebut cukup beralasan, di wilayah perkotaan dan semi perkotaan hubungan antar individu secara pelan namun pasti bertransformasi dari hubungan berpola paguyuban (gemeinschaft) ke hubungan berpola patembayan (gesselschaft) ${ }^{22}$. Pola hubungan paguyuban yang berciri kebersamaan dan saling peduli pada masalah sesama anggota komunitas mulai digeser oleh pola patembayan yang berciri hubungan transaksional. Dalam derajat tertentu, pola patembayan diikuti dengan lemahnya kontrol sosial masyarakat terhadap sesama. Dengan pola interaksi seperti ini yang diikuti perubahan pola gaya hidup yang cenderung "serba permisif" mengakibatkan meningkatnya kasus kehamilan pranikah. Di satu sisi, pola "serba permisif" banyak pula dipengaruhi oleh stimulasi seksual dari lingkungan berupa tayangan media rnassa dan hiburan komersial dengan beragam bentuk dan intensitas. Secara umum budaya pop dan komersialisasi hiburan secara gencar lebih mengkampanyekan aspek kenikmatan seks daripada aspek tanggung jawabnya. ${ }^{23}$ Dalam kondisi ini - dalam derajat tertentu - dapat dipahami "runtuhnya" daya tahan remaja dalam menghadapi kebanjiran stimulasi seksual yang mengakibatkan kehamilan pranikah dan selanjutnya diikuti oleh tindakan aborsi.

Meski demikian, secara kritis bisa ditarik generalisasai bahwa aborsi dilakukan tidak hanya dikarenakan kehamilan di luar perkawinan (kehamilan pranikah, dilakukan gadis), tetapi juga terjadi di dalam perkawinan, oleh perempuan yang berstatus istri. Baik abortus dikarenakan kehamilan di luar perkawinan ataupun dalam perkawinan keduanya memiliki beberapa alasan yang berbeda, dan keduanya merupakan fenomena terselubung yang cenderung ditutupi oleh pelakunya. Tabel 1 berikut memberikan gambaran beberapa alasan aborsi.

${ }^{21}$ Ibid.

${ }^{22}$ Khisbiyah, Ibid.

${ }^{23}$ Ibid., hal. 34. 
Tabel 1 Jenis/Alasan Aborsi

\begin{tabular}{|l|c|}
\hline Jenis/Alasan Melakukan Abortus & $\%$ \\
\hline Abortus Spontaneous & 25 \\
\hline Abortus Provokatus Terapikus & 10 \\
\hline Abortus Spontaneous Kriminalis & - \\
\hline Malu, takut & 15 \\
\hline Sudah memiliki anak, tidak ingin hamil lagi & 40 \\
\hline Belum ingin memiliki anak & 5 \\
\hline Disuruh suami & 1 \\
\hline Jumlah & 100 \\
\hline
\end{tabular}

Sumber: Penelitian laparon, 1997

Dengan disyahkannya Undang-Undang Nomor 36 Tahun 2009 . Tentang Kesehatan (UU Kesehatan) menggantikan undang-undang kesehatan sebelumnya yaitu Undang-Undang Nomor 23 tahun 1992. Dalam UU Kesehatan, permasalahan aborsi memperoleh legitimasi dan penegasan. Secara eksplisit, dalam undang-undang ini terdapat pasal-pasal yang mengatur mengenai aborsi, meskipun dalam praktek medis mengandung berbagai reaksi dan menimbulkan kontroversi diberbagai lapisan masyarakat. Meskipun, undang-undang melarang praktik aborsi - tetapi dalam keadaan tertentu terdapat kebolehan. Ketentuan pengaturan aborsi dalam UU Kesehatan dituangkan dalam Pasal 75, Pasal 76 dan Pasal 77.

\section{Pasal 75}

(1) Setiap orang dilarang melakukan aborsi.

(2) Larangan sebagaimana dimaksud pada ayat (1) dapat dikecualikan berdasarkan:

a. indikasi kedaruratan medis yang dideteksi sejak usia dini kehamilan, baik yang mengancam nyawa ibu dan/atau janin, yang menderita penyakit genetik berat dan/atau cacat bawaan, maupun yang tidak dapat diperbaiki sehingga menyulitkan bayi tersebut hidup di luar kandungan; atau

b. kehamilan akibat perkosaan yang dapat menyebabkan trauma psikologis bagi korban perkosaan.

(3) Tindakan sebagaimana dimaksud pada ayat (2) hanya dapat dilakukan setelah melalui konseling dan/atau 
penasehatan pra tindakan dan diakhiri dengan konseling pasca tindakan yang dilakukan oleh konselor yang kompeten dan berwenang.

(4) Ketentuan lebih lanjut mengenai indikasi kedaruratan medis dan perkosaan, sebagaimana dimaksud pada ayat (2) dan ayat (3) diatur dengan Peraturan Pemerintah.

Pasal 76

Aborsi sebagaimana dimaksud dalam Pasal 75 hanya dapat dilakukan:

a. sebelum kehamilan berumur 6 (enam) minggu dihitung dari hari pertama haid terakhir, kecuali dalam hal kedaruratan medis;

b. oleh tenaga kesehatan yang memiliki keterampilan dan kewenangan yang memiliki sertifikat yang ditetapkan oleh menteri;

c. dengan persetujuan ibu hamil yang bersangkutan;

d. dengan izin suami, kecuali korban perkosaan; dan

e. penyedia layanan keséhatan yang memenuhi syarat yang ditetapkan oleh Menteri.

Pasal 77

Pemerintah wajib melindungi dan mencegah perempuan dari aborsi sebagaimana dimaksud dalam Pasal 75 ayat (2) dan ayat (3) yang tidak bermutu, tidak aman, dan tidak bertanggung jawab serta bertentangan dengan norma agama dan ketentuan peraturan perundang-undangan.

Berdasarkan ketentuan UU Kesehatan tersebut jika kita kaitkan dengan aborsi KTD akibat perkosaan, maka dapat menyimpulkan: Pertama, secara umum paraktik aborsi dilarang; Kedua, larangan terhadap praktik dikecualikan pada beberapa keadaan, kehamilan akibat perkosaan yang dapat menyebabkan trauma psikologis bagi korban perkosaan. Selain itu tindakan medis terhadap aborsi KTD akibat perkosaan hanya dapat dilakukan apabila: (1) setelah melalui konseling dan/atau penasehatan pra tindakan dan diakhiri dengan konseling pasca tindakan yang dilakukan oleh konselor yang kompeten dan berwenang; (2) dilakukan sebelum kehamilan berumur 6 (enam) minggu dihitung dari hari pertama haid terakhir, kecuali dalam hal kedaruratan medis; (3) oleh tenaga kesehatan yang memiliki 
keterampilan dan kewenangan yang memiliki sertifikat yang ditetapkan oleh menteri; (4) dengan persetujuan ibu hamil yang bersangkutan; dan (5) penyedia layanan kesehatan yang memenuhi syarat yang ditetapkan oleh Menteri.

Kesimpulannya, bahwa UU Kesehatan memperbolehkan praktik aborsi terhadap kehamilan akibat perkosaan dengan persyaratan dilakukan oleh tenaga yang kompeten, dan memenuhi ketentuan agama dan perundang-undangan yang berlaku.

\section{Analisis Hukum Islam}

Islam merupakan agama yang menjunjung tinggi kesucian kehidupan. Hal ini dibuktikan dengan sejumlah ayat-ayat dalam alQur'an yang bersaksi terhadap hal tersebut. Ketentuan-ketentuan dapat kita lihat dalam surat 5 ayat 23 , bahwa:

Barang siapa yang membunuh seorang manusia, bukan karena sebab-sebab yang mewajibkan hukum qishash, atau bukan karena membuat kerusuhan di muka bumi, maka seakan-akan telah membunuh manusia seluruhnya. Dan barang siapa yang memelihara keselamatan nyawa seorang manusia, maka seolah-olah ia telah memelihara keselamatan seluruh manusia semuanya..

Sementara dalam surat al-Isro' (17) ayat 31 dan 33, juga dijelaskan:

Dan janganlah kamu membunh anak-anakmu karena takut melarat. Kamilah yang memberi rejeki kepada mereka dan kepadamu juga. Sesunguhnya membunuh mereka adalah dosa yang besar.

Dan janganlah kamu membunuh nyawa seseorang yang dilarang Allah, kecuali dengan alasan yang benar.

Berdasarkan ayat-ayat tersebut, Islam memberikan landasan hukum yang jelas bahwa kehidupan manusia itu suci sehingga haruslah dipelihara dan tidak boleh dihancurkan (diakhiri) kecuali dilakukan untuk suatu sebab atau alasan yang benar, seperti dalam eksekusi hukuman mati atau dalam perang, atau dalam pembelaaan diri yang dibenarkan. Berikutnya akab dianalisis pandanganpandangan ulama fikh tentang aborsi, argumentasi methodologis (usul fikh), solusi fikh, dan argumentasi fikh aborsi. 


\section{Pandangan Ulama Fikih Tentang Aborsi}

Yusuf Qardhawi mengatakan, bahwa pada umumnya merujuk pada ketentuan hukum Islam, praktik aborsi adalah dilarang dan merupakan kejahatan terhadap makhluk hidup oleh sebab itu hukuman sangat berat bagi mereka yang melakukannya ${ }^{24}$. Hal yang sama dikemukakan oleh Muhammad Mekki Naciri, bahwa semua literatur hukum Islam dari mazhabmazhab yang ada sepakat untuk mengatakan, bahwa aborsi adalah perbuatan aniaya dan sama sekali tidak diperbolehkan kecuali jika aborsi didukung dengan alasan yang benar. ${ }^{25}$ Meski demikian pendapat para ulama berkaitan dengan kasus di atas yang berakhir dengan aborsi sangat beragam, khusunya dalam hal penentuan bilakah dibolehkannya pengguguran kandungan dengan alasan yang dibenarkan tersebut.

Ulama dari madzhab Hanafi membolehkan pengguguran kandungan sebelum kehamilan berusia 120 hari dengan alasan belum terjadi penciptaan ${ }^{26}$. Pandangan sebagian ulama lain dari madzhab ini hanya membolehkan sebelum kehamilan berusia 80 hari dengan alasan penciptaan terjadi setelah memasuki tahap mudghah atau janin memasuki usia 40 hari kedua. ${ }^{27}$ Mayoritas ulama Hanabilah membolehkan pengguguran kandungan selama janin masih dalam bentuk segumpal darah ('alaqah) karena belum berbentuk manusia. ${ }^{28}$ Syafi'iyah melarang aborsi dengan alasan kehidupan dimulai sejak konsepsi, di antaranya dikemukakan oleh Al-Ghazali dalam Ihya Ulumuddin, tetapi sebagian lain dari mereka yaitu Abi Sad dan Al-Qurthubi membolehkan. Namun AlGhazali dalam Al-Wajiz pendapatnya berbeda dengan tulisannya dalam Al-Ihya, beliau mengakui kebenaran pendapat bahwa

${ }^{24}$ Yusuf al-Qardhawi, "al-Halal wa al-Haram fi al-Islam", (Kairo: Maktabah alWabah, 1980), hal. 169

${ }^{25}$ Abul Fadl Mohsin Ebrahim, "Biomedical Issues, Isamic Perspektive", Terj. "Aborsi, Kontrasepsi, dan Mengatasi Kemandulan”, (Jakarta: Mizan, 1997), hal. 156.

${ }^{26}$ Ibnu Abidin. Tt. "Hasyiyah Rad al-Mukhtar 'ala al-Dur al-Mukhtar", Jilid 2 (Beirut: Daar al-Fikr, tanpa tahun), hal. 411.

${ }^{27}$ Ibid., hal. 302 .

${ }^{28}$ Abi Muhammad Abdullah bin Ahmad bin Muhammad bin Qudamah. Tt. " $A l$ Mughni", Jilid 2, (Cairo: Hajar, tanpa tahun), hal. 210. 
aborsi dalam bentuk segumpal darah ('alaqah) atau segumpal daging (mudghah) tidak apa-apa karena belum terjadi penyawaan. ${ }^{29}$ Kecuali mayoritas ulama Malikiyah melarang aborsi. Landasan hukum yang digunakan sebagai argumentasi bagi ulama-ulama tersebut adalah dua hadis Nabi berikut:

Dari Abi Abd Rahman Abdillah bin Mas'ud RA berkata: Rasulullah menceritakan kepada kami sesungguhnya seseorang dari kamu kejadiannya dikumpulkan dalam perut ibumu selama 40 hari berupa nuthfah, kemudian menjadi segumpal darah ('alaqah) dalam waktu yang sama, kemudian menjadi segumpal daging (mudghah) juga dalam waktu yang sama. Sesudah itu malaikat diutus untuk meniupkan roh ke dalamnya dan diutus untuk melakukan pencatatan empat perkara, yaitu mencatat rizkinya, usianya, amal perbuatannya dan celaka atau bahagia. (HR. Muslim). ${ }^{30}$

Aku mendengar Rasulullah SAW bersabda bahwa apabila nutfah telah melewati empat puluh dua hari, Allah mengutus malaikat untuk membentuk rupanya, menjadikan pendengarannya, penglihatannya, kulitnya, dagingnya, dan tulangnya, kemudian malaikat bertanya: Wahai Tuhanku, apakah dijadikan laki-laki atau perempuan? Lalu Allah menentukan apa yang dikehendaki, lalu malaikat itu pun menulisnya. (HR. Muslim). ${ }^{3 l}$

Namun demikian pandanagn ahli fikh yang membolehkan aborsi tersebut dalam realitas sosial tidak dapat dijadikan alternatif bagi perempuan yang tidak menghendaki kehamilannya. Meskipun demikian, dalam konteks Indonesia berdasarkan Keputusan Fatwa Musyawarah Nasional VI Majelis Ulama Indonesia (MUI) Nomor: I/MUNAS VI/MUI/2000 tanggal 29 Juli 2000 ditetapkan:

${ }^{29}$ Al-Ghazali. Tt. “Al-Wajiz”, (Beirut: Daar Al-Ma'rifah, tanpa tahun), hal. 158.

${ }^{30}$ Abi Al-Husain Muslim bin Al-Hajjaj Al-Qusyairy Al-Naisabury, "Sahih Muslim", hadis nomor 2643, Jilid 2 (Libanon, Beirut: Daar Al-Fikr, 1992), hal. 549.

${ }^{31}$ Ibid., hadis nomor 2645, hal. 550. 
(1) Melakukan aborsi (pengguguran janin) sesudah nafkh alruh hukumnya adalah haram, kecuali jika ada alasan medis, seperti untuk menyelamatkan jiwa si ibu;

(2) Melakukan aborsi sejak terjadinya pembuahan ovum, walaupun sebelum nafkh al-ruh, hukumnya adalah haram, kecuali ada alasan medis atau alasan lain yang dibenarkan oleh syari'ah Islam;

(3) Mengharamkan semua pihak untuk melakukan, membantu atau mengizinkan aborsi.

Ketetapan MUI tersebut, apabila dicermati bahwa pada dasarnya sebagaimana ahli fikh umumnya, MUI mengharamkan praktik aborsi termasuk di dalamnya pihak yang turut serta melakukan, membantu dan mengizinkan aborsi. Meski demikian terdapat kebolehan aborsi apabila memenuhi beberapa unsur: Pertama, melakukan aborsi sebelum ditiupkannya ruh (nafkh alruh); Kedua, melakukan aborsi sebelum ditiupkannya ruh ( $n a f k h$ al-ruh), hanya boleh dilakukan apabila: (1) jika ada alasan medis, seperti untuk menyelamatkan jiwa si ibu; dan (2) ada alasan lain yang dibenarkan oleh syari'ah Islam.

Perdebatan di antara ahli fikih dalam hal aborsi tersebut, jika kita amati, akar perdebatannya adalah pada batas kehidupan. Sejak kapan sesungguhnya kehidupan itu dimulai? Bahasa yang digunakan teks sulit sekali diklarifikasi, hanya menyatakan "sebelum tercipta" atau "sebelum menjadi manusia" (qabla takhalluq). Al-Qur'an menyebutkan proses pentahapan penciptaan manusia terdiri dari nutfah, 'alaqah dan mudghah, kemudian Allah menjadikan makhluk dalam bentuk lain, sebagaimana diinformasikan Q.S. Al-Mukminun/23:12-14) berikut:

Sesungguhnya Kami telah menciptakan manusia itu dari saripati tanah. Kemudian Kami jadikan saripati itu menjadi air mani yang tersimpan di tempat yang aman dan kokoh. Dalam perkembangan selanjutnya, air mani itu Kami olah menjadi segumpal darah, dan segumpal darah itu Kami olah menjadi segumpal daging. Lalu segumpal daging itu Kami olah menjadi tulang belulang. Selanjutnya tulang belulang itu Kami bungkus dengan daging. Selanjutnya Kami jadikan makhluk yang berbentuk lain dari yang sebelumnya. Maha Suci Allah Pencipta yang Paling Baik. 
Dalam ayat tersebut tidak menjelaskan secara tegas kapan sesungguhnya memasuki kehidupan sebagai manusia, apakah sejak tersimpan dalam rahim atau istilah kedokteran sejak zigot melekat dalam endometrium yang disebut dengan nidasi (implantasi) atau apakah sejak Tuhan menjadikannya sebagai makhluk yang berbentuk lain dari yang sebelumnya (khalqan aakhar).

Kata khalqan berasal dari khalaqa artinya penciptaan. Di dalam Al-Qur'an ditemukan makna yang sama antara khalaqa dan ja'ala, seperti khalaqa minha zaujaha (An-Nisa/4:1) dan ja'ala minha zaujaha (Al-A'raf/7:189), keduanya memiliki arti yang sama. Tetapi dalam hal penciptaan ini, kata khalaqa menunjukkan kemahakuasaan dan kehebatan Allah yang tiada tara, sedangkan kata ja'ala hanya menunjukkan bahwa penciptaan itu dari materi yang sudah ada, yakni nafs waahidah (satu jenis dari bahan baku yang sama). Al-Qur'an juga menunjukkan bahwa penciptaan dengan kata khalq bersifa gradual, seperti manusia berasal dari percampuran antara spermatozoa laki-laki dan ovum perempuan, kemudian menjadi zigot, embrio dan seterusnya. ${ }^{32}$ Sedangkan kata khalqan aakhar, artinya binafkhi alruh fiih, dengan meniupkan ruh ke dalam penciptaannya. ${ }^{33}$

Mengenai batas awal kehidupan manusia kapan persisnya roh ditiupkan, di dalam hadis pun tidak dijelaskan, hanya disebutkan bahwa proses sperma (nutfah) berlangsung selama 40 hari pertama, 40 hari kedua berupa segumpal darah ('alaqah) dan 40 hari ketiga berupa segumpal daging (mudghah), setelah itu baru ditiupkan roh. Tetapi roh itu apa? Tidak ada penjelasan secara rinci, hanya disebut bahwa roh adalah urusan Tuhan. Tetap misterius hingga sekarang, karena hanya Tuhan yang mengetahui, sebagaimana disebutkan Al-Qur'an surat Al-Israa'/ 17:85 tadi.

Teks tersebut adalah fakta yang menginformasikan bahwa roh adalah otoritas Tuhan, kapan ditiupkan ke dalam jiwa manusia menjadi kehidupan dan kapan dilepaskan dari dalam jiwa manusia menjadi sebuah kematian tidak ada seorang pun yang mengetahui. Meskipun proses kehidupan dan kematian tersebut seluruhnya

${ }^{32}$ Quraish Shihab, "Ensiklopedi Al-Qur'an Kajian Kosakata an Tafsirnya", (Jakarta: Yayasan Bimantara, 1997), hal. 210.

${ }^{33}$ Jalaluddin Muhammad bin Ahmad Al-Mahally dan Jalaluddin Abd Rahman bin Abi Bakr Al-Suyuuthy. Tt., "Tafsir Al-Jalalain", (Surabaya: Al-Hidayah, tanpa tahun), hal. 1617. 
merupakan hukum alam (sunnatullah), tetapi tidak seluruhnya transparan dapat diketahui manusia karena ada rahasia alam yang menjadi domain Tuhan yang disebut metafisik (gha'ib), hanya bisa dirasakan tetapi tidak dapat diinderakan.

Secara eksplist dari hadis di atas tertangkap informasi bahwa roh ditiupkan ke dalam janin setelah 40 hari ketiga atau setelah kehamilan berusia 120 hari. Sementara dalam Al-Qur'an, dengan kata khalqan aakhar yang memiliki arti ditiupkan roh kedalam janin (binafkhi al-ruuh fiih) menunjukan bahwa proses pembentukan manusia sudah berakhir saat roh ditiupkan kedalam janin. Setelah itu, janin disebut menjadi makhluk yang lain yang secara substansial telah memiliki akal dan raga. Berbeda dengan sebelumnya yang secara substansi hanya memiliki raga tetapi belum berakal. Mengenai waktunya, saat kehamilan usia berapa hari peniupan roh tersebut terjadi, menjadi rahasia Tuhan sejak ayat tersebut turun hingga sekarang. Hal tersebut diakui oleh Gulardi Wignjosastro ${ }^{34}$, pakar kebidanan dan kandungan dari Fakultas Kedokteran Universitas Indonesia bahwa tidak ada satu alat pun yang dapat mendeteksi kapan kehidupan manusia itu dimulai.

\section{Argumentasi Methodologis (Ushul fiqh)}

Fikih sebagai sebuah ilmu yang berisi seperangkat hukumhukum Islam yang bersifat praktis (amaliyah) harus mampu menjembatani antara hakikat hukum yang dikehendaki Tuhan (Syari') dengan realitas kehidupan yang dialami manusia sebagai pelaksana hukum. Seluruh tindakan manusia baik berupa transaksi antar sesama manusia (mu'amalah) maupun yang bersifat transendental hanya berhubungan dengan Tuhan (ibadah) di dalam syari'at Islam telah diatur hukum-hukumnya. Ketentuan normatif tersebut secara umum (universal) telah diatur di dalam Al-Qur'an berupa teks (nash) sebagai sumber utama pembentukan hukum Islam yang dijadikan pedoman hidup bagi umat Islam. Namun tidak seluruh teks Al-Qur'an menjelaskan secara tegas dan mudah ditangkap maksudnya tetapi membutuhkan penjelasan untuk memahami isinya yang sebagian ada di dalam hadis dan sebagian lain membutuhkan penafsiran karena hadis tidak menjelaskannya.

${ }^{34}$ Gulardi H. Wignjosastro dalam Maria Ulfah Anshor, Op. Cit. 
Nash di dalam Al-Qur'an maupun hadis ada dua macam: pertama, bersifat pasti (qath'iy) yaitu dikemukakan dengan bahasa yang tegas, memiliki arti yang jelas, tidak ada makna lain yang terkandung di dalamnya kecuali yang tersurat dan tidak membutuhkan penafsiran, atau disebut dengan ayat-ayat muhkamat. Teks-teks tersebut mengandung prinsip-prinsip universal, bersifat mutlak, tidak terbatas pada ruang dan waktu. Kedua, bersifat menduga-duga (dzanny) yaitu dikemukakan dengan bahasa yang tidak tegas, memiliki banyak arti yang memungkinkan untuk ditafsirkan dengan makna lain (interpretable), atau disebut dengan ayat-ayat mutasyabihat. Teksteks tersebut terbatas pada ruang dan waktu tertentu, bersifat khusus. ${ }^{35}$ Teks-teks yang tidak tegas inilah yang menjadi lahan penggalian hukum dalam menyelesaikan berbagai persoalan kehidupan manusia yang tidak ditemukan jawabannya di dalam Al-Qur'an maupun hadis.

Untuk mengeluarkan hukum dari teks-teks yang bersumber dari Al-Qur'an maupun hadis baik secara tekstual (dzahir nash) maupun yang tersirat dari jiwa dan semangat teks (kontekstual) di masa Rasulullah masih hidup tidak ada persoalan, karena beliau langsung memandunya dan apabila menemukan ketidak jelasan hukum para sahabat dapat menanyakan langsung kepada beliau. Tradisi penggalian hukum terhadap persoalan-persoalan kehidupan yang tidak ditemukan hukumnya di dalam teks AlQur'an maupun hadis sudah dilakukan oleh para sahabat Nabi. Bahkan Rasulullah memotivasi keberanian para sahabat dan umatnya yang memiliki kemampuan untuk menggali hukum (ijtihad) supaya diperoleh ketetapan hukum yang dinamis sesuai dengan situasi dan kondisi zaman, sebagaimana sabda beliau:

Apabila seorang hakim hendak menetapkan sesuatu hukum dengan berijtihad kemudian ijtihadnya tepat, maka baginya mendapat dua pahala. Dan apabila ia hendak menetapkan suatu hukum dengan berijtihad kemudian ijtihadnya salah, maka baginya mendapat satu pahala. $^{36}$

${ }^{35}$ Abdul Wahab Khallaf, "Kaidah-kaidah Hukum Islam (Ushul Figh)", (Bandung: Penerbit Risalah, 1985), hal. 44. 
Selain itu, Nabi juga mengajarkan dan melatih kepada para sahabatnya mengenai bagaimana cara-cara mengeluarkan hukum dari dalil-dalilnya yang bersifat universal tersebut supaya dapat diterjemahkan ke dalam realitas kehidupan nyata. Sikap tersebut dapat dilihat dalam dialog antara Nabi dengan Mu'adz bin Jabal ketika hendak diutus beliau ke Yaman, beliau bersabda:

Bagaimana anda memutuskan suatu hukum ketika
anda diminta untuk menentukan suatu keputusan?"
Jawab Mu'adz: "Aku akan memutuskan dengan kitab
Allah". Rasulullah bertanya lagi; "jika anda tidak
menemukan di dalam kitab Allah?" Mu'adz
menjawab: "dengan sunnah Rasulullah". Rasul
bertanya lagi; "jika anda tidak menemukan di dalam
sunnah Rasul-Nya?" Jawab. Mu'adz; "aku akan
melakukan ijtihad dengan pendapatku, dan aku tidak
akan menyempitkan ijtihadku". Mu'adz lalu berkata;
Rasulullah kemudian menepuk-nepuk dadaku dengan
tangan beliau sambil mengucapkan; "segala puji bagi
Allah yang telah memberikan petunjuk terhadap
utusan Rasul dengan jalan yang direstui oleh
Rasulullah. ${ }^{37}$

Begitu juga dengan kondisi sekarang di mana banyak kejadian yang ditimbulkan oleh tuntutan zaman yang terus berubah seringkali membutuhkan kepastian hukum, bahkan sama sekali tidak pernah terjadi dalam kehidupan di masa Rasulullah dan para sahabatnya. Di sinilah peran fikih untuk menentukan ketetapan dan penjelasan terhadap masalah-masalah tersebut berdasarkan pada dalil-dalil agama (syar'iyyah).

Dalil-dalil agama secara umum bersumber pada empat landasan pokok, yaitu: 1) Al-Qur'an, 2) Hadis (As sunnah), 3) Kesepakatan para ulama (Ijma') dan 4) Analogi hukum (Qiyas). Menurut mayoritas ulama (jumhur al-ulama), keempat landasan tersebut disepakati sebagai dalil. Selain itu, mereka sepakat bahwa

${ }^{36}$ Abi Al-Husain Muslim bin Al-Hajjaj Al-Qusyairy Al-Naisabury. 261 H. Shahih Muslim. Beirut: Daar Al-Fikr, 1992, jilid 2, hal. 123, hadis nomor 15.

37 Syamsuddin Abi Abdillah Muhammad bin Abi Bakr, Jilid 1, "A'laam alMuwaqqi'iin 'an Rabb al-'Aalamiin", (Cairo: Maktabah Al-Kulliyaat Al-Azhar, 1980), hal. 202. Lihat juga Ibrahim Hoesen, "Fikih Perbandingan dalam Masalah Nikah, Thalaq, Rujuk dan Hukum Kewarisan", (Jakarta: Balai Penerbitan dan Perpustakaan Islam Yayasan Ihya Ulumuddin Indonesia, 1971), hal. 4. 
cara penggunaan dalil tersebut secara kronologi sebagaimana urutan yang tersebut di atas. ${ }^{38}$ Dengan kata lain, jika terjadi suatu permasalahan yang membutuhkan pemecahan hukum Islam maka upaya yang dilakukan adalah mencari dalil atau hukum di dalam Al-Qur'an. Jika di dalam Al-Qur'an itu ditemukan hukumnya maka hukum tersebut yang dilaksanakan. Tetapi jika di dalam AlQur'an tidak ditemukan hukumnya, maka mencarinya di dalam hadis. Bila ditemukan hukumnya di dalam hadis maka hukum itu yang harus dilaksanakan. Bila di dalam hadis ternyata tidak ditemukan hukumnya maka harus melihat pada hasil kesepakatan para penggali hukum (mujtahid), apabila ketentuan hukum tersebut ditemukan maka hukum itu harus dilaksanakan. Tetapi tidak menutup kemungkinan untuk dilakukan penggalian hukum (ijtihad) ${ }^{39}$ sendiri dengan cara menganalogikan terhadap persoalan yang sudah ada hukumnya (qiyas). ${ }^{40}$

Jadi, karakter fikih pada prinsipnya adalah dapat diterapkan (applicable), menawarkan solusi terhadap persoalan-persoalan kehidupan yang dialami manusia dan mengantarkan pada kesejahteraan atau kemaslahatan umum (al-mashalih al-'ammah). Hal tersebut sebagaimana ditegaskan dalam kaidah pembentukan hukum Islam bahwa tujuán utama pembentukan hukum Islam (maqashid al-syari'ah) adalah merealisir kemaslahatan bagi kehidupan manusia dengan mendatangkan kesejahteraan dan menjauhkan bahaya dalam kehidupan mereka. Kemaslahatan manusia itu dapat terwujud apabila terjamin kebutuhan pokok (dharuriyah), kebutuhan sekunder (hajiyah) maupun kebutuhan pelengkapnya (tahsiniyah). ${ }^{41}$

\section{Mencari Solusi dengan Fikih Alternatif}

Dalam konteks aborsi tak aman yang menimbulkan tingginya angka kematian ibu, bukan merupakan persoalan sederhana, tetapi

\section{${ }^{38}$ Abdul Wahab Khallaf, Op. Cit., hal. 17.}

${ }^{39}$ Ijtihad secara bahasa berarti kesungguhan, menurut istilah ulama ushul dalam Abdul Wahab Khallaf adalah mencurahkan daya kemampuan secara sungguh-sungguh untuk mengeluarkan hukum Islam (syari'ah) dari dalil-dalil agama (syara') secar rinci.

${ }^{40}$ Abdul Wahab KHallaf, Op. Cit, hal. 18.

${ }^{41}$ Ibid., bagian kedua, hal. 137. 
memiliki dimensi sosial yang kompleks baik secara fisik, psikis bagi yang bersangkutan maupun psiko-sosial bagi lingkungannya. Fikih dalam hal ini harus berorientasi pada etika sosial yang produk hukumnya tidak sekedar halal atau haram, boleh dan tidak boleh, tetapi harus memberikan jawaban berupa solusi hukum terhadap persoalan-persoalan sosial yang dihadapi perempuan. Dengan kata lain, diakui pula oleh K.H. Sahal Mahfudz (2003): "Fikih sosial bertolak dari pandangan bahwa mengatasi masalah sosial yang kompleks dipandang sebagai perhatian utama syari'at Islam". 42

Dalam konteks menetapkan kepastian hukum mengenai tingginya angka kematian ibu akibat aborsi tak aman yang merupakan dua kondisi yang sama-sama membahayakan, dapat dianalisa dengan menggunakan beberapa kaidah fikih, antara lain: pertama, "Bahaya itu menurut agama harus dihilangkan (al-dlarar yuzaalu syar'an)"; kedua, "Bahaya yang lebih berat dapat dihilangkan dengan memilih bahaya yang lebih ringan (al-dharar al-asyadd yuzaalu bi al-dharar al-akhaff)" atau "Jika dihadapkan pada dua kondisi yang sama-sama membahayakan, maka pilihlah bahaya yang lebih kecil risikonya (Idza ta'aaradlat almafsadataani ruu'iya a'dhamuhuma dlararan)"; ketiga, "Keterpaksaan dapat memperbolehkan untuk melakukan hal-hal yang dilarang (al-dlaruraatu tubiihul mahdzuraat)"; keempat, perubahan hukum Islam dapat dilakukan dengan adanya perubahan zaman, perubahan tempat, perubahan kondisi, perubahan niat dan kultur atau adat (taghayyir al-ahkam bitaghayyur al-azminah wal-amkinah wal-ahwal wan-niyaat wal'awaaid)". 43

Ada argumentasi klasik di kalangan ulama bahwa pencegahan atau mendahulukan prevensi (syaddu al-dzari'ah) lebih baik. Dalam hal hukum aborsi, melarang aborsi dianggap lebih aman, karena ada kehawatiran kalau aborsi dibolehkan akan dijadikan sebagai peluang bagi pelaku seks di luar nikah mencari jalan keluar. Bila aborsi dibolehkan sama dengan memberikan

${ }^{42}$ Sahal Mahfudh, M.A. 2003. Fikih Sosial: Upaya Pengembangan Madzhab Qauli dan Madzhab Manhaji, Pidato Promovendus pada Penerimaan Gelar Doktor Honoris Causa dalam Bidang Fikih Sosial di UIN Syarif Hidayatullah, Jakarta, 18 Juni 2003, hal. 18.

${ }^{43}$ Syamsuddin Abi Abdillah Muhammad bin Abi Bakr (terkenal dengan panggilan Ibnu Qayyim Al-Juuziyyah), "Alaam al-Muwaqqi'iin 'an Rabbi al-'Alamiin", Jilid 3, (Cairo: Mathabi' Al-Islam, 1980), hal. 3. 
kesempatan untuk melakukan perzinahan atau seks bebas. Pertanyaannya adalah bagaimana fikih menjawab realitas yang sudah terjadi berupa tingginya angka aborsi tak aman yang jelasjelas mengancam kematian, apakah masih relevan menjawab dengan argumentasi preventif. Pandangan tersebut nampak sangat tekstual karena hanya berorientasi pada teks tanpa melihat realitas sosial bahwa ada kondisi yang mengancam kematian perempuan yang perlu dijembatani supaya aborsi tak aman tidak terjadi. Di sinilah letak kesenjangannya antara teks fikih dan kenyataan di lapangan.

Argumentasi klasik tersebut terpatahkan dengan ditemukannya fakta bahwa dari jumlah rata-rata 2 juta kasus aborsi pertahun, $76.6 \%$ dilakukan oleh perempuan berstatus menikah. ${ }^{44}$ Penelitian terakhir oleh Yayasan Kesehatan Perempuan (2003), 87\% klien aborsi berstatus menikah. ${ }^{45}$ Mereka memutuskan aborsi ternyata ada sejumlah persoalan kemanusiaan yang mempengaruhinya. Beberapa faktor penentu di antaranya perkosaan dan incest, kegagalan alat kontrasepsi, kemiskinan, kesehatan fisik maupun mental dan sebagainya. Dari jumlah aborsi tersebut diperkirakan $10-50 \%$ nya berakhir dengan kematian ibu. ${ }^{46}$

Dari sudut pandang apapun fakta tersebut adalah merupakan problem sosial yang sangat memprihatinkan, harus dicarikan solusinya, tidak cukup hanya dengan wacana, etis atau tidak etis maupun kontroversi lainnya. Kita dihadapkan pada fakta yang sudah ada di depan mata, menuntut siapapun untuk segera bersikap dan bertindak. Terlepas dari takdir, kesakitan dan kematian akibat aborsi tak aman tersebut sesungguhnya dapat cegah setidaknya dikurangi.

Mengingat fikih adalah dimaksudkan untuk mengatur seluruh prilaku kehidupan manusia supaya dapat hidup lebih bermanfaat dan maslahat, begitu juga hukum positif dibuat untuk mengatur seluruh prilaku warga negara supaya berbuat sesuai

${ }^{44}$ Budi Utomo. Op. Cit., hal. 30.

${ }^{45}$ Ninuk Widyantoro, "Pengakhiran Kehamilan Tak Diinginkan yang Aman Berbasis Konseling", (Jakarta: Yayasan Kesehatan Perempuan, 2003).

46 WHO dalam Gulardi Wignyosastro. Masalah Kesehatan Perempuan Akbat Reproduksi, Makalah Seminar Penguatan Hak-Hak Reproduksi Perempuan, PP Fatayat NU dan Ford Foundation, Jakarta, 1 September 2001 
hokum. Maka perlu dilakukan kompromi dalam proses pembentukan hokum antara realitas kehidupan dengan nilai-nilai yang dikehendaki oleh teks. Dengan demikian, kesenjangan antara hukum Islam (fikih) yang memilik karakter lentur dan dinamis dengan hukum positif yang kaku dan melarang tindakan aborsi sebagaimana dalam Undang-undang nomor 23 tahun 1992 tentang Kesehatan khususnya pasal $15^{47}$ dapat dijembatani. Sehingga upaya penguatan terhadap hak-hak reproduksi perempuan dapat terlaksana sesuai dengan kesepakatan ICPD tanpa harus larut atau terpengaruh dengan budaya negara lain.

Pendapat-pendapat para ulama mengenai aborsi tersebut dapat dijadikan sebagai ilustrasi bahwa karakter fikih adalah dinamis dan realistis dapat dikaji secara terus menerus sesuai dengan perkembangan masyarakat, termasuk di dalamnya perkembangan ilmu pengetahuan dan teknologi modern. Hal tersebut sejalan dengan tujuan pembentukan hukum Islam (maqaashid al-ahkam al-syar'iyyah), sebagaimana dikatakan Hasbi Ash-Shiddieqy yaitu mencegah terjadinya kerusakan dalam kehidupan manusia dan mendatangkan kemaslahatan kepada mereka, mengendalikan dunia dengan kebenaran, keadilan dan kebajikan serta menerangkan cara yang harus dilaluinya dengan menggunakan akal manusia. ${ }^{48} 26$ Dalam hal ini, yang terpenting kuncinya adalah fikih itu harus bisa mencegah terjadinya kerusakan dan mendatangkan kemaslahatan secara proporsional terhadap kehidupan manusia.

Prinsip-prinsip di dalam kaidah pembentukan hukum Islam tersebut dalam praktik hampir sama dengan prinsip-prinsip dasar moral dalam ilmu filsafat, yang harus berpegang pada tiga prinsip dasar yaitu $^{49}$; pertama, prinsip sikap baik yaitu bersikap positif

${ }^{47}$ Pasal 15, ayat (1): Dalam keadaan darurat sebagai upaya untuk menyelamatkan jiwa ibu hamil dan atau janinnya, dapat dilakukan tindakan medis tertentu. Ayat (2): Tindakan medis tertentu sebagaimana dimaksud dalam ayat (1) hanya dapat dilakukan: a) berdasarkan indikasi medis yang mengharuskan diambilnya tindakan tersebut. b) Oleh tenaga kesehatan yang mempunyai keahlian dan kewenangan untuk itu dan dilakukan sesuai dengan tanggung jawab profesi serta berdasarkan pertimbangan tim ahli. c) Dengan pesetujuan ibu hamil yang bersangkutan atau suami atau keluarga. d) Pada sarana kesehatan tertentu. Ayat (3): Ketentuan lebih lanjut mengenai tindakan medis tertentu sebagaimana dimaksud dalam ayat (1) dan ayat (2) ditetapkan dengan peraturan pemerintah.

${ }^{48}$ Hasbi Ash Shiddieqy, Op. Cit., hal. 177. 
dan baik. Sikap ini menjadi kesadaran inti utilitarianisme bahwa kita harus mengusahakan akibat-akibat baik sebanyak mungkin dan mengusahakan untuk sedapat-dapatnya mencegah akibatakibat buruk dari tindakan kita dengan tanpa merugikan pihak lain; kedua, prinsip keadilan yaitu perlakuan yang sama terhadap semua orang sesuai dengan haknya masing-masing. Prinsip ini menuntut kita agar tidak mencapai tujuan-tujuan, termasuk yang baik, dengan melanggar hak orang lain.; ketiga, prinsip hormat terhadap diri sendiri, yaitu selalu memperlakukan diri sebagai sesuatu yang bernilai pada dirinya sendiri.

\section{Argumantasi Fikih Aborsi KTD akibat Perkosaan}

\section{Aborsi KTD}

Upaya pencegahan terhadap KTD adalah paling ideal, jauh lebih baik secara normatif maupun dari sisi hukum apapun dan agama manapun dibanding dengan aborsi. Namun jika alat kontrasepsi yang digunakan ternyata gagal tidak berhasil menghalangi bertemunya sperma dan ovum hingga terjadi KTD, maka harus dicarikan jalan keluar yang proporsional, rasional dan tidak bertentangan dengan agama. Perdebatan antara Pro dan kontra mengenai aborsi tidak memberikan solusi apapun dalam mengatasi masalah kematian ibu akibat aborsi tak aman.

Untuk merumuskan aborsi alternatif yang aman baik dari sisi agama, kesehatan maupun psikologi perlu dilakukan bersama antara pembuat hukum (legislatif dan eksekutif) dengan para pakar dan praktisi di bidangnya masing-masing mengenai batasan-batasan aman dari segi kesehatan, aman dari segi kejiwaan (psikologis), aman dari sosio-ekonomis dan aman menurut agama (syara'). Begitu juga batasan-batasan darurat dan maslahat yang sesuai dengan kaidah agama harus mengacu pada situasi dan kondisi fisik maupun psikis, tempat dan kultur yang kontekstual. Melalui proses tersebut, diharapkan ada ketentuan mengenai aborsi aman yang berorientasi pada solusi untuk penguatan hak reproduksi perempuan dan upaya pencegahan terhadap kematian ibu.

Persoalan lain yang terus menerus menyertai perdebatan berkaitan dengan aborsi adalah mengenai batasan darurat, meskipun secara

49 Franz Magnis-Suseno, "Etika Dasar: Masalah-masalah Pokok Filsafat Moral", (Yogyakarta: Kanisius, 1987), hal. 130-134. 
agama (syar'i) sangat jelas yaitu apapun yang dapat mengancam kebinasaan terhadap agama, jiwa, akal, keturunan dan harta (addlaruuriyyat al-Khamsah) disebut darurat. Artinya, segala situasi dan kondisi apapun yang dapat mengantarkan atau mengakibatkan pada rusaknya lima perkara tersebut dapat dilakukan meskipun harus bertentangan dengan hal-hal yang dalam situasi normal dilarang, misalnya memakan sesuatu yang diharamkan untuk obat diperbolehkan.

Dalam hal ini, ketika dihadapkan pada dua kondisi yang samasama membahayakan, maka dapat memilih salah satu kondisi yang tingkat bahayanya paling ringan, sebagaimana kaidah fikih mengatakan: "yang lebih ringan di antara dua bahaya bisa dilakukan demi menjaga yang lebih membahayakan (yartakibu akhaff aldhararaiin li ittiqaa'i asyaddahuma)" ${ }^{50}$ Kaidah lain menyebutnya: "Jika dihadapkan pada sebuah dilema yang sama-sama membahayakan, maka ambillah risiko yang paling kecil dengan menghindari sesuatu risiko yang lebih besar (idzaa t'aaradhat almafsadataani ruu'iya a'dzamuhuma dhararan". ${ }^{\text {.1 }}$

Namun pemahaman-pemahaman mengenai batasan bahaya (dlarurat) tersebut dalam hal aborsi seringkali terjebak pada ukuranukuran fisik, padahal dalam konteks manusia antara fisik dan psikis itu tidak dapat dipisahkan. Seseorang yang kondisi fisiknya sehat belum tentu secara psikis sehat, begitu juga sebaliknya. Oleh karena itu, faktor fisik dan psikis tidak dapat dipisahkan, keduanya harus menjadi ukuran dalam mempertimbangkan bahaya atau tidaknya seseorang. Termasuk di dalamnya seluruh situasi dan kondisi yang menjadi latar belakang, menjadi perantara atau penyebab yang mengantarkan (washilah) terjadinya kondisi darurat menjadi bagian yang juga harus dianalisa dalam menetapkan hukum.

Pertimbangan-pertimbangan tersebut sebagai dasar pembentukan hukum tidak dapat dipisahkan dengan tujuan untuk mewujudkan kemaslahatan $30^{52}$ terhadap ibunya, karena ibu merupakan induk (al$a s h l$ ) dari janin sehingga harus dipertahankan dan harus dilindungi. Ibu telah memiliki tanggung jawab kemanusiaan tèrhadap keluarganya maupun masyarakatnya. Sementara janin belum memiliki tanggung

${ }^{50}$ Abdul Wahab Khallaf, Op. Cit., hal. 151.

${ }^{51}$ Al-Suyuthi. Tt. Al-Asybah Wa Al-Nadza'ir, hal. 62

52 Pengertian maslahat adalah mengambil kemanfaatan dan menolak bahaya (jalbul manfa'ah wa daf'ul madlaarah). 
jawab apapun. Dalam hal ini sifatnya memang relatif sekali, tidak bisa digeneralisir secara hitam puth karena kondisi yang dianggap dlarurat dan maslahat bagi seseorang belum tentu sama dengan kondisi darurat dan maslahat bagi orang lain.

Tetapi di situlah sebenarnya justru terletak keunikan fikih, bersifat relatif, memiliki fleksibilitas, sangat tergantung pada situasi dan kondisi bahkan motivasi (niat) yang melatar belakangi, sebagaimana kaidah klasik yang dikemukakan oleh Ibnu Qayyim Al-Jauziyah di atas. Kaidah lain menyebutkan bahwa hukum sangat tergantung pada adanya 'illat dan tidak adanya 'illat (al-hukm yaduuru ma'a al-'illah wujuudan wa- 'adaman) ${ }^{53}$

Berdasarkan kaidah-kaidah tersebut dengan mempertimbangkan aspek-aspek kebaikan dan kemanfaatan (mashlahat) dan bahaya (madlarat) baik secara fisik maupun psikis dan faktor-faktor lain yang mempengaruhi KTD, maka fikih aborsi alternatif dapat dirumuskan. Hal tersebut sebagai salah satu upaya penguatan hak-hak reproduksi perempuan untuk menghindari terjadinya kematian ibu akibat aborsi tak aman. Pengertian alternatif di sini adalah sebagai pilihan terakhir bagi perempuan yang situasi dan kondisi fisik maupun psikisnya memang tidak memungkinkan kalau kehamilannya dilanjutkan. Dalam proses pengambilan keputusan tersebut harus berdasarkan ukuranukuran yang ditentukan oleh perempuan yang bersangkutan bukan oleh pihak lain termasuk suami atau keluarganya, karena dia dalam hal KTD adalah pihak yang paling mengetahui dan memiliki otonomi terhadap dirinya.

Adapun fikih aborsi alternatif yang dimaksudkan sebagai solusi yang diusulkan di sini adalah dilakukan segera setelah diketahui terjadi KTD hingga sebelum usia kehamilan melewati 8 minggu atau janin berusia 6 minggu (42 hari).

Berdasarkan pertumbuhan embrio, pada kehamilan usia 0-8 minggu embrio dalam proses pertumbuhan sel yang belum sempurna dan diduga kuat peniupan roh belum terjadi. Kondisi embrio pada usia tersebut nyaris sama dengan yang diinformasikan hadis Nabi bahwa Allah mengutus malaikat untuk menyempurnakan proses pembentukan manusia adalah setelah embrio melewati usia 42 hari. Secara lengkap hadis tersebut berbunyi sebagai berikut:

${ }^{53}$ Sulaiman, Jaml Fath Al-Wahab, Jilid 4, (Cairo: Daar Al-Ihya, tanpa tahun), hal. 183. 
Aku mendengar Rasulullah SAW bersabda bahwa apabila nuthfah telah melewati empat puluh dua hari, Allah mengutus malaikat untuk membentuk rupanya, menjadikan pendengarannya, penglihatannya, kulitnya, dagingnya, dan tulangnya, kemudian malaikat bertanya: Wahai Tuhanku, apakah dijadikan laki-laki atau perempuan? Lalu Allah menentukan apa yang dikehendaki, dan malaikat itupun menulisnya. (Hadis Riwayat. Muslim). ${ }^{54}$

Jadi, berdasarkan hadis tersebut didukung dengan kaidah-kaidah fikih, dengan mempertimbangkan pertumbuhan embrio dan hak-hak reproduksi, maka aborsi alternatif dapat dilakukan sebagai pilihan terakhir dalam kondisi darurat setelah upaya lain berupa pencegahan KTD tidak berhasil dilakukan. Dengan syarat, dilakukan sesuai Standar Operasional Prosedur (SOP) profesi kesehatan serta melalui proses konseling sebelum maupun sesudah aborsi dilakukan (pre abortion and post abortion). Dengan demikian, fikih aborsi alternatif dapat mendukung upaya penguatan hak reproduksi perempuan dalam menghindari KTD maupun mencegah terjadinya kematian ibu.

\section{Aborsi KTD Akibat Perkosaan}

Meskipun perkosaan merupakan kejahatan seksual, jika ditinjauan dari sisi wanitanya perkosaan sama sekali tidak sama dengan perzinahan dan pergaulan seks bebas, karena perkosaan melibatkan pemaksaan dan kekerasan. Dimana salah satu pihak, terutama wanita tidak memiliki kemauan untuk melakukannya. Hal inilah yang membedakan dengan perzinahan ataupun pergaulan bebas yang pada umumnya sebagai didorong oleh perasaan mau sama mau.

Islam memiliki prinsip, bahwa pencegahan lebih diutamakan, begitupun dalam kasus pemerkosaan. Pemecahan secara Islami terhadap kasus perkosaan adalah mengakhiri segala bentuk pengeksposan tubuh di depan publik; melarang film-film pornografi, buku dan nyanyian; membatasi pergaulan bebas antara pria dan wanita; dan tidak menggunakan wanita sebagai daya tarik iklan untuk menjual segala macam produk atau barang. Di atas segalanya, orang yang bersalah melakukan perkosaan harus dihukum di depan publik. Tetapi, bila langkah-langkah pencegahan telah diambil tetapi

${ }^{54}$ Abi Al-Husain Muslim bin Al-Hajjaj Al-Qusyairy Al-Naisabury, "Shahih Muslim", hadis 2645, Jilid 2, (Beirut: Daar Al-Fikr, 1992), hal. 550. 
perkosaan tetap terjadi, maka Islam menganjurkan agar korban segera mendapatkan pertolongan medis untuk mencegah segala kemungkinan terjadinya kehamilan. Pendapat ini diperkuat dengan pandangan Qurthubi yang mengatakan bahwa air mani bukanlah sesuatu yang pasti (yaqinan), dan tidak ada konsekuensinya jika wanita segera 'mengeluarkannya sebelum ia menetap dalam rahim ${ }^{55}$. Dan juga, secara medis, segera setelah tindakan seksual terjadi, seperti dalam kasus perkosaan, tidak mungkin mengetahui apakah kehamilan telah terjadi. Karena itu, diperbolehkan pada saat itu mendapat pengobatan untuk mencegah kehamilan. Tetapi, jika tidak ada tindakan yang diambil untuk melaporkan perkosaan dan juga tidak diambil tindakan medis untuk mencegah kemungkinan hamil, maka tampaknya tidak dibenarkan untuk menganjurkan aborsi setelah beberapa hari atau bulan berlalunya perkosaan. Karena nantinya, secara medis akan sulit menentukan apakah perkosaan memang benar-benar terjadi. Dan hal ini bisa mengarah pada penyalahgunaan tujuan.

Menurut Ebrahim, dalam rangka pencegahan terhadap KTD akibat perkosaan dapat dilakukan dengan melakukan kegiatan antara lain: Pertama, menciptakan lingkungan Islami yang di dalamnya masyarakat membersihkan segala bentuk godaan untuk menjamin tidak terjadinya perkosaan tentu saja sikap yang patut dipuji. Tetapi ini tidak begitu saja menjamin bahwa perkosaan tidak terjadi. Selalu saja ada pengecualian. Benar bahwa hukuman keras yang dijatuhkan Islam kepada mereka yang bersalah melakukan seks bebas dan perzinaan dapat menjadi langkah pencegahan terhadap tindak perkosaan. Tetapi hukum Islam tersebut hanya dapat diterapkan dalam negara Islam. Dengan demikian, menganjurkan pelaksanaan hukum tersebut sebagai pencegahan terhadap tindakan perkosaan tidak akan menyelesaikan persoalan. Karena hukum tersebut tidak pernah diterapkan di negaranegara bukan Islam. Tetapi, bahkan di negara Islam, kecuali Arab Saudi, Iran dan Pakistan, hukum Islam ini tidak ditegakkan.

$K e d u a$, jika setiap wanita segera meminta pertolongan medis setelah diperkosa, maka tindakan ini tentu saja akan menyelesaikan persoalan aborsi, yaitu mengakhiri kehamilan akibat perkosaan. Tetapi, di negara atau wilayah Islam tidaklah mudah bagi korban perkosaan untuk melaporkan perkosaan karena mereka takut akan diasingkan. Mengasingkan wanita yang mengalami perkosaan tentu saja perbuatan yang tidak Islami, tetapi masyarakat

${ }^{55} \mathrm{Abu}$ 'Abd Allah Muhammad ibn Ahmad al-Ansari al-Qurtubi, "Al-Jami' fi Ahkan al-Qur'an”, (Kairo: Maktabah al-Wabah, 1967), hal. 8. 
cenderung menganggap rendah mereka dan bahkan peluang mereka untuk menikah akan terancam. Karena itu, yang umum terjadi adalah bahwa setelah kehamilan tampak barulah dipikirkan tindakan apa yangharus dilakukan. ${ }^{56}$

Tidak ada keraguan bahwa akan mustahil secara medis untuk menentukan apakah perkosaan memang benar-benar terjadi. Tetapi, adilkah baginya untuk terus hamil sampai tiba saatnya melahirkan dan anak yang dilahirkan, diberi label sebagai anak haram? Joseph Fletcher mengatakan bahwa pada prinsipnya adalah kehamilan seharusnya terjadi karena pilihan, bukan karena paksaan. ${ }^{57}$ Memaksanya agar tetap hamil sampai tiba waktunya tentu saja bertentangan dengan pendapat mengenai AID. Dikatakan bahwa kasus sperma donor adalah haram dan karena itu tidak dapat diterima sebagai cara untuk hamil. Dengan demikian kasus kehamilan akibat perkosaan pun bisa tergolong haram.

Dalam kasus KTD akibat perkosaan -itupun terjadi pada seorang wanita, apakah aborsi dibenarkan? Dalam kasus ini sebagian orang cenderung mengatakan setuju dengan memandang, bahwa perbuatan seksusal dilakukan pada wanita sengan paksaan, tidak atas kemauannya. Karena itu harus dikatakan bahwa wanita mempunyai hak untuk tidak mengandung anak seseorang yang tidak memiliki ikatan emosional dengannya.

Pernah terjadi seorang istri diperkosa sewaktu suaminya berada di negara lain untuk melakukan bisnis. Apakah dia akan menerima bahwa istrinya mengandung anak dari laki-laki lain? Tentu tidak, istrinya sendiri akan gelisah menunggu sampai lahirnya anak dari orang yang telah merasukinya dengan suatu pengalaman yang traumatis. Ini kejadian nyata. Penulis cenderung untuk berpendapat bahwa dalam kasus kehamilan akibat perkosaan, aborsi boleh dibenarkan. Tetapi adilkah ini? Lagi pula, janin ini tidak melakukan kejahatan apa pun, mengapa dia tidak diizinkan untuk hidup?

\section{Penutup}

Aborsi pada dasarnya adalah fenomena yang hidup dalam masyarakat Indonesia. Aborsi dapat dikatakan sebagai fenomena "terselubung" karena

${ }^{56}$ Abul Fadl Mohsin Ebrahim, Op. Cit., hal. 148-149

57 Joseph Fletcher, "Humanhood: Essays in Biomedical Ethics", (Tanpa kota.: Prometheus Books, 1979), hal. 138. 
praktik aborsi sering tidak tampil ke permukaan, bahkan cenderung ditutupi oleh pelaku ataupun masyarakat, bahkan negara. Ketertutupan ini antara lain dipengaruhi oleh hukum formal dan nilai-nilai sosial, budaya, agama yang hidup dalam masyarakat serta politik.

Hukum Islam maupun Undang-Undang Nomor 39 tahun 2009 samasama memandang bahwa aborsi adalah suatu kejahatan (tindak pidana), sehingga memberikan hukuman bagi siapa saja yang melakukannya.

Meskipun demikian Hukum Islam maupun Undang-Undang Nomor 39 tahun 2009 memberikan 'kebolehan' aborsi pada kasus:

(1) apabila kehamilan tersebut akan membahayakan bagi ibu dan janin;

(2) kehamilan tidak diharapakan akibat perkosaan.

Kebolehan aborsi tersebut harus merujuk pada ketentuan-ketentuan medis, sehingga dalam praktiknya tidak membawa akibat yang lebih buruk bagi si ibu, dan terutama dalam hukum Islam haruslah merujuk pada syar'i yang telah ditetapkan. 


\section{Daftar Pustaka}

\section{Buku}

Abidin, Ibu. Hasyiyah Rad al-Mukhtar 'ala al-Dur al-Mukhtar. Beirut: Daar al-Fikr, tanpa tahun terbit.

Abi Al-Husain Muslim bin Al-Hajjaj Al-Qusyairy Al-Naisabury. Sahih Muslim. Libanon, Beirut: Daar Al-Fikr, 1992.

Abi Muhammad Abdullah bin Ahmad bin Muhammad bin Qudamah. Tt. Al-Mughni. Cairo: Hajar.

Al-Ghazali. Tt. Al-Wajiz. Beirut: Daar Al-Ma'rifah.

Al-Suyuthi. Tt. Al-Asybah Wa Al-Nadza'ir.

Anshor, M.U. 2000. Fikih Aborsi dan Penguatan Hak Kesehatan Reproduksi. Makalah disampaikan pada Forum Fatayat NU, Jakarta 21 Maret 2000.

Anshor, M.U. 2001. Penguatan Hak Kesehatan Reproduksi dalam Komunitas Islam. Makalah disampaikan pada Forum Fatayat NU, Jakarta 1 September 2001.

Departemen Agama RI. 2003. Himpunan Fatwa Majelis Ulama Indonesia. Jakarta: Departemen Agama RI.

Dewi, M. U. H. 1997, Aborsi: Pro dan Kontra di Kalangan Petugas Kesehatan, Yogyakarta: Pusat penelitian Kependudukan UGM dan Ford Foundation.

Ebrahim, A.F.M. Biomedical Issues, Islamic Perspective. Terj. Meutia, Sari. 1997. Aborsi, Kontrasepsi, dan Mengatasi Kemandulan. Jakarta: Mizan.

Ekotama, dkk., 2001, Abortus Provocatus Bagi Korban Perkosaan: Perspektif Viktimologi, Kriminologi dan Hukum Pidana. Yogyakarta: Universitas Atmajaya.

Guttmacher Institute. 2008. Aborsi di Indonesia. Guttmacher Institute. Seri 2008, No. 2.

Hoesen, Ibrahim. Fikih Perbandingan dalam Masalah Nikah, Thalaq, Rujuk dan Hukum Kewarisan. Jakarta: Balai Penerbitan dan Perpustakaan Islam Yayasan Ihya Ulumuddin Indonesia, tanpa tahun terbit. 
Indraswari. Fenomena Kawin Muda dan Aborsi: Gambaran Kasus, dalam Hasyim, Syafiq, Menakar Harga Perempuan, Eksplorasi atas Hak-Hak Reproduksi Perempuan dalam Islam. Jakarta: Mizan, 1999.

Jalaluddin Muhammad bin Ahmad Al-Mahally dan Jalaluddin Abd Rahman bin Abi Bakr Al-Suyuuthy. Tafsir Al-Jalalain. Surabaya: Al-Hidayah, tanpa tahun terbit.

Khallaf, Abdul Wahab. Kaidah-kaidah hukum Islam (Ushul Figh). Bandung: Penerbit Risalah, 1985.

Magnis-Suseno, Franz. 1987. Etika Dasar: Masalah-masalah Pokok Filsafat Moral. Yogyakarta: Kanisius.

Royston, E., dan Armstrong, S. (Eds). Preventing Maternal Deaths, Terj. Maulany, R. F., Pencegahan Kematian Ibu Hamil. Jakarta: Binarupa Aksara, 1994.

Shihab, Quraish. Ensiklopedi Al-Qur'an Kajian Kosakataan Tafsirnya. Jakarta: Yayasan Bimantara, 1997.

Sulaiman. Jaml Fath Al-Wahab. Cairo: Daar Al-Ihya, tanpa tahun terbit.

Syamsuddin Abi Abdillah Muhammad bin Abi Bakr. 'Alaam alMuwaqqi'iin 'an Rabbi al-'Alamiin, Cairo: Mathabi' Al-Islam, 1980.

Tafal, dkk., eds., Keguguran, Jakarta: ITF Netherlands, IPPF, dan PKBI, 1999.

Widyantoro, Ninuk. Pengakhiran Kehamilan Tak Diinginkan yang Aman Berbasis Konseling. Jakarta: Yayasan Kesehatan Perempuan, 2003.

\section{Internet/Artikel Koran/Makalah/Disertasi}

<http://www.rajawana.com/artikel.html/227-aborsi.pdf.htm>, diakses tanggal 1 Maret 2010.

"2 Juta Perempuan Per Tahun Lakukan Aborsi", Harian Terbit, Jum'at 23 Mei 2003.

"Keselamatan Ibu: Keberhasilan dan Tantangan". Out Look, Vol. 16, Edisi Khusus, Januari 1999. 
Mahfudh, Sahal. "Fikih Sosial: Upaya Pengembangan Madzhab Qauli dan Madzhab Manhaji", Pidato Promovendus pada Penerimaan Gelar Doktor Honoris Causa dalam Bidang Fikih Sosial di UIN Syarif Hidayatullah. Jakarta, 18 Juni 2003, Jakarta: Universitas Islam Negeri.

Soge, P. "Pengaruh Perkembangan Kehidupan Masyarakat Terhadap Pengaturan Hukum Tentang Aborsi di Indonesia", Disertasi, Yogyakarta: Universitas Gadjah Mada. Tidak Dipublikasikan, 2008 .

Supriyadi," "Politik Hukum Kesehatan terhadap Pengguguran Kandungan", Makalah disampaikan dalam Diskusi Ilmiah, "Aborsi Dari kajian Ilmu Politik Hukum", (Hukum Kesehatan dan Hukum Pidana), Yogyakarta: Bagian Hukum Pidana, FHUAJY, tanggal 2 Juli 2002.

The Alan Guttmacher Institute (AGI), "Sharing Responsibility: Women, Society and Abortion Worldwide", New York: AGI dalam Martha S. Ismail. Promosi Kesehatan Reproduksi: Pencegahan Kehamilan yang Tidak Diinginkan/Kehamilan yang Tidak Direncanakan.

Utomo, B., dkk. "Angka Aborsi dan Aspek Psiko-sosial di Indonesia: Studi di 10 kota Besardan 6 Kabupaten", Jakarta: Pusat Penelitian Kesehatan Universitas Indonesia, 2002.

Wignyosastro, G. "Masalah Kesehatan Perempuan Akbat Reproduksi, Makalah Seminar Penguatan Hak-Hak Reproduksi Perempuan", diselenggarakan PP Fatayat NU dan Ford Foundation, Jakarta, 1 September 2001. 